\title{
Reading a Duty to Provide Accessible Pre-Contractual Information for Consumers with Disabilities into EU Consumer Protection Law
}

\section{Waddington ${ }^{1}$ (D)}

Received: 8 July 2021 / Accepted: 31 January 2022 / Published online: 28 February 2022

(c) The Author(s) 2022, corrected publication 2022

\begin{abstract}
This paper considers whether a duty to provide consumers with disabilities with pre-contractual information in an accessible format, or in an otherwise personalised format, can be read into EU consumer protection law. Such a duty could be regarded as a particular form of reasonable accommodation. The paper explores this issue in the context of three key consumer protection instruments: the Unfair Commercial Practices Directive, the Consumer Credit Directive, and the Consumer Rights Directive. The paper argues that the Directives should be interpreted in light of the EU's obligations under the UN Convention on the Rights of Persons with Disabilities (CRPD) which addresses, inter alia, the accessibility of information. Whilst consumer protection is an area of shared competence between the EU and its Member States, the three Directives examined in the paper largely provide for "full harmonisation," thereby limiting the scope Member States have for taking action in these fields. In light of this, the paper argues that the EU has, to a large degree, taken on responsibility for complying with the CRPD in these fields, and that the Directives should be interpreted in light of those obligations. The EU Charter of Fundamental Rights can further bolster a human rights compatible interpretation of EU consumer protection directives. The paper also considers the extent to which the Directives allow Member States some residual competences to set requirements concerning pre-contractual information for persons with disabilities. To the extent that such competences exist, the paper argues that CRPD-compatible minimum requirements for pre-contractual information provided to consumers with disabilities should be read into the Directives by the European Court of Justice. Establishing CRPD-compatible minimum requirements in this field would reduce the need for individual Member States to take action to comply with the CRPD, and therefore reduce the risk of divergent national standards which could undermine the internal market goals of the relevant Directives. The paper concludes that a duty to provide a de facto reasonable accommodation, in terms of accessible and additional information, can be read into the Consumer Credit Directive and the Consumer Rights Directive. A more limited duty, concerning only the provision of additional information for persons with disabilities, can be read into the Unfair Commercial Practices Directive. It is unclear whether case law of the Court of Justice can be interpreted as requiring the provision of accessible information under this last Directive.
\end{abstract}

Extended author information available on the last page of the article 
Keywords EU consumer protection law - UN Convention on the Rights of Persons with Disabilities · Pre-contractual information · Accessible information

The EU has developed an extensive body of law and policy designed to protect consumers in the internal market. The overall goal of the policy is "protecting consumers from serious risks and threats that they are unable to tackle as individuals; empowering them to make choices based on accurate, clear and consistent information; enhancing their welfare and effectively protecting their safety as well as their economic interests" (Valant, 2015, p. 3). The provision of relevant and accurate pre-contractual information to consumers is a key element of this policy, and is seen as a means of empowering consumers. This is based on the assumption that, given such information, consumers can decide on an informed basis to enter into a contract and to be bound by all the contractual obligations (Howells et al., 2018 , p. 96). Informed consent can be understood as "a tool to educate consumers by providing information considered to be important before agreeing to be administered service" (Griffiths, 2014, p. 208). In this context, information disclosure is regarded as a way to address asymmetries of bargaining power between consumers and traders (Mak, 2012) and as a means of overcoming market failures (Hesselink, 2007).

The "average consumer," who is deemed to be reasonably well informed, observant and circumspect (Directive 2005/29; C-122/10 Konsumentombudsmannen v Ving Sverige AB, para. 22; Unberath \& Johnston, 2007, p.1237), is an important benchmark in determining the duty of traders to provide consumers with pre-contractual information (Howells et al., 2018, p. 27). Under this neoclassical economic approach (Hesselink, 2007), the trader should consider the "average consumer" when deciding what pre-contractual information to provide and the format in which to provide it. However, a number of EU consumer protection directives also recognise that some consumers are "particularly vulnerable," and consumers with disabilities (specifically consumers with "mental or physical infirmity" (Directive 2005/29, Art. 5(3)) are sometimes explicitly identified as "vulnerable" in this context. At the same time, these directives do not clearly indicate what steps traders should take to ensure that consumers with disabilities have access to pre-contractual information which they can understand, and on the basis of which they can give informed consent. Nevertheless, it is submitted that a requirement to take additional steps to provide those consumers with disabilities who have difficulty understanding pre-contractual information provided in the standard format (e.g., information on paper or in a pdf document attached to an email), with information that they can understand (e.g., information in Braille, in a Microsoft Word document or in easy-to-read text), can be read into EU consumer protection law and relevant national legislation. This requirement may also apply in the context of the information provided, meaning that some consumers with disabilities should be provided with different or additional pre-contractual information compared to other consumers. This paper reflects on the extent of this obligation, and whether this can be understood as a form of de facto reasonable accommodation for consumers with disabilities to enable them to give informed consent.

The paper first introduces the situation of consumers with disabilities, and explores the barriers to accessing information which consumers with a disability can face. The paper then examines the relevant international law framework, focusing on the UN Convention on Persons with Disabilities (CRPD) to which the EU is a party. The relevance of the EU Charter of Fundamental Rights is also briefly addressed. This framework is discussed in the context of consumer protection and with regard to those areas of law in which the EU 
has largely established full (as opposed to minimum) harmonisation. Subsequently, the paper presents the concept of reasonable accommodation, which plays a prominent part in international, EU, and domestic disability non-discrimination law. The paper then moves on to explore EU consumer protection law, and reflects on the extent to which a duty to provide a de facto reasonable accommodation to meet the needs of disabled consumers can be read into that law.

Having stated what this paper does address, it is also important to note what it does not cover. The paper does not question whether the provision of pre-contractual information is the best way of empowering consumers with and without disabilities in the market; nor does it reflect on whether the use of the language of "vulnerability" in EU consumer protection law is the most appropriate way of addressing the situation of consumers with disabilities. However, I have argued strongly against both of these approaches in other publications (Waddington, 2020, 2013), and will not repeat those arguments here. Instead, this article is about the implications of EU consumer protection law, as it currently stands, for the provision of accessible pre-contractual information to consumers with disabilities.

\section{Consumers with Disabilities in Europe: Legal Issues and Concepts}

Almost a quarter of EU residents identify as disabled. Specifically, in the EU 27 in 2018, about $24.5 \%$ of persons aged 16 and over declared themselves to have a disability (being limited), with $7.0 \%$ of the population declaring a severe disability (being severely limited) and about $17.5 \%$ declaring a moderate disability (being moderately limited) (Grammenos, 2020). While the number of persons identifying as disabled is substantial, this group is not uniform, and is made up of people with many different kinds of impairments, including physical, mental, intellectual, and sensory impairments. Disability can impact in a number of ways in the context of consumer transactions. Most radically, individuals with disabilities can be denied legal personhood, through a declaration of legal incapacity, and that can lead to an individual being legally unable to enter into a valid contract. ${ }^{1}$ However, there are also other more pernicious ways in which individuals with disabilities can be hampered in their role as consumers, including through the lack of access to pre-contractual information which they can understand.

Eskyté has argued that "limited provision of consumer information in alternative formats leads people with vision, hearing, or cognitive impairments to misguided shopping decisions, financial loss, while constraining their consumer experience" and that "people with impairments are rarely fully informed" (Eskyté, 2019, pp. 524-525). As noted above, disabled people are a diverse group, and have different needs in terms of the format in which information is provided. Accessible formats can include texts in Braille, large print, audio, sign language, text-based information, documents in Microsoft Word, and easy-to-read texts and symbols. In order to be accessible to the full range of non-disabled and disabled consumers, information needs to be presented in a variety of forms. Eskyté has revealed, for example, that promotional flyers, which contain pictures and company logos, can be a good way for people with cognitive impairments to obtain information, but the use of small fonts and glossy paper which reflects light means that they are difficult for some people with impaired vision to read

\footnotetext{
1 This highly important issue is not discussed further in this paper. For further information see Article 12 CRPD and Yvette Maker et al (2018).
} 
(Eskyté, 2019, p. 530). Therefore the distinctive visual images (Beudaert, 2018, p. 370) which make such flyers eye catching for people without visual impairments and which are helpful for people with cognitive impairments can also render the flyers inaccessible for people with certain visual impairments. The latter group may require information to be presented on paper, without certain colour contrasts and in large print or in another format, such as a Microsoft Word document, which can easily be read using screen reader technology.

In addition to providing information in an alternative format, it may be necessary to provide some consumers with disabilities with additional information, beyond that provided to most consumers, including information on the particular risk or benefit a product or service could present for a person with their impairment or health condition. In this context, a different format refers to the provision of exactly the same information in a different (non-standard) format, whilst different content refers to information being presented and communicated either using different language and terminology, or providing additional information which is not provided to other consumers, but which is particularly important for a consumer with a (particular) disability to know. This could involve including personalised examples of the implications of entering into a contract.

A 2019 EU Directive, the European Accessibility Act (EEA) (Directive (EU) 2019/882), addresses how information can be made accessible to consumers with disabilities in the context of certain products or services. It provides that instructions for use of a product (Directive (EU) 2019/882, Annex I, Section I and Annex II) should be made available via more than one sensory channel (e.g., through electronic files which can be read by a computer using screen readers); be presented in an understandable way (e.g., using the same words in a consistent manner, or in a clear and logical structure, so that persons with intellectual disabilities can better understand them); be presented to users in ways they can perceive (e.g., providing subtitles in video instructions); be presented in fonts of adequate size and suitable shape; be made available in text formats that can be used for generating alternative assistive formats (e.g., printing in Braille); be accompanied by an alternative presentation of any non-textual content (e.g., accompanying a diagram with a text description identifying the main elements or describing key actions); include a description of the user interface of the product; include a description of the functionality of the product which is provided by functions aiming to address the needs of persons with disabilities; and include a description of the software and hardware interfacing of the product with assistive devices. The relevance of the EAA, in terms of providing information to consumers with disabilities to enable them to make an informed decision before entering into a contract, is discussed further below in the section on "Post-CRPD Consumer Protection Directives and the Duty to Provide Pre-Contractual Accessible Information".

In terms of the responsibility to provide information on the basis of which a consumer can make an informed decision, Griffiths argues that "if the process of informed consent is to be truly collaborative, the interests of both parties [trader and consumer] must be considered and covered. Given that the service provider has the greater level of control the responsibility for protection rests there." (Griffiths, 2014, p.215). The following sections reflect on the nature and degree of the obligation placed on traders to provide disabled consumers with accessible information under EU law. 


\section{The UN Convention on the Rights of Persons with Disabilities and the EU and Consumer Protection}

The CRPD is the first core human rights treaty which specifically addresses the rights of persons with disabilities, and is the first human rights treaty to which the EU has become a party. As a consequence, the EU is bound by the Convention to the extent of its competences and, since the EU's conclusion of the Convention in December 2010, references to the CRPD have been included in numerous pieces of secondary legislation (e.g., Directive (EU) 2019/882 (European Accessibility Act (EAA) and Directive (EU) (2016/2102) (on the accessibility of the websites and mobile applications of public sector bodies)), although not, thus far, in consumer protection legislation falling under the auspices of the Commission Directorate General Justice and Consumers.

The Convention explicitly recognises that "disability results from the interaction between persons with impairments and attitudinal and environmental barriers that hinders their full and effective participation in society on an equal basis with others" (Preamble, recital (e) and Article 1). The Convention therefore acknowledges that disability stems from the failure of the social environment to meet the needs and aspirations of people with impairments. This includes the disabling role played by inaccessible information.

The scope of the Convention is extremely broad (Quinn, 2007, p. 9). While the Convention is underpinned by the principles of non-discrimination and equality, which embrace the right to a reasonable accommodation, these are linked to a broad group of rights. These rights are both civil and political, such as the right to liberty (Article 14), as well as more substantive, such as the right to education (Article 24). ${ }^{2}$ Melish therefore argues that the Convention adopts a "hybrid approach" (Melish, 2007, footnote 11).

Aside from the right to a reasonable accommodation, which is addressed below, the CRPD contains a number of provisions which seem particularly relevant in the context of accessible information, including with regard to information provided by the private sector, such as traders operating in the internal market.

Firstly, the removal of obstacles and barriers to accessibility lies at the heart of Article 9 CRPD. Article 9(1) requires State Parties to take "appropriate measures to ensure to persons with disabilities access, on an equal basis with others, ... to information and communications." These measures should include "the identification and elimination of barriers to accessibility" including with regard to "information communication and other services." This provision is supplemented by Article 9(2) which requires appropriate measures:

(b) To ensure that private entities that offer facilities and services which are open or provided to the public take into account all aspects of accessibility for persons with disabilities

(f) To promote other appropriate forms of assistance and support to persons with disabilities to ensure their access to information

As a consequence, State Parties are under an obligation to impose a duty to provide accessible facilities and services, including in the context of (pre-contractual) information, on private parties.

2 This paragraph draws on text in Lisa Waddington (2011). 
A second relevant provision is Article 21, concerning freedom of expression and opinion, and access to information. This provision requires State Parties to "take all appropriate measures to ensure that persons with disabilities can exercise the right to freedom of expression and opinion, including the freedom to seek, receive and impart information and ideas on an equal basis with others and through all forms of communication of their choice." This obligation is explicitly stated to apply in the context of private entities that provide services to the general public, including through the Internet, which are to be urged "to provide information and services in accessible and usable formats for persons with disabilities" (Article 21(c)).

Whilst consumer protection or information for consumers is not specifically mentioned in the CRPD, it is clear that, when interpreted in a holistic way, and in light of the Convention's goal to "promote, protect and ensure the full and equal enjoyment of all human rights and fundamental freedoms by all persons with disabilities, and to promote their inherent dignity" (Article 1), traders are to be obliged to address the accessibility of information provided to consumers with disabilities. Maker et al. have also argued that a number of economic and social rights in the International Covenant on Economic, Social and Cultural Rights can "only be fully implemented through the introduction of consumer protection measures", and, similar to the present author, regard the CRPD, and particularly Articles 5, 9 , and 21, as relevant in the context of information provision to consumers with disabilities (Maker et al., 2018, pp. 182-184 citing Deutch, 1994, p. 562; Eskyté, 2019; Lazer, 2019, p. 188).

\section{Implications of the UN Convention on the Rights of Persons with Disabilities and the EU Charter of Fundamental Rights for EU Consumer Protection Law}

The paper now considers the implications of the CRPD for EU consumer protection law, especially in light of the fact that the CRPD is a mixed agreement, involving concurrent jurisdictions of both the Member States and the EU. ${ }^{3}$ In principle, consumer protection is an area of shared competence, ${ }^{4}$ meaning that the Member States remain free to act collectively, individually or jointly with the Union to fulfil the obligations under international agreements (C-316/91 Re: European Development Fund), and sole responsibility does not fall on the EU to implement the CRPD in such an area. However, the situation is different where the EU has exercised its legislative competence and established "common rules" (as opposed to minimum standards) in a specific area. This is set out in the Declaration concerning the Competence of the European Community (now EU) with regard to matters governed by the United Nations Convention and the Rights of Persons with Disabilities (Council Decision 2010/48/EC, Annex II). The Declaration specifies that, in some of the fields that were initially presented as falling within the scope of shared competences, the EU in fact has exclusive competence. This is "to the extent that provisions

\footnotetext{
3 This text draws on Lisa Waddington, (2011).

4 Article 4 TFEU provides that the Union shares competence with the Member States where the Treaties confer on it a competence which does not relate to Article 3 (exclusive competence) or Article 6 (competence to carry out actions to support, coordinate or supplement the actions of the Member States). Article 4(2) TFEU lists a number of areas where competences are shared, including the internal market, social policy as defined in the TFEU, and transport.
} 
of the Convention or legal instruments adopted in implementation thereof affect common rules previously established by the European Community." 5 The EU then in fact has exclusive competence where the Convention affects existing-or presumably new-EU provisions that establish "common rules," from which the Member States cannot deviate. In such fields, internal EU action has "occupied the whole field" and has pre-empted Member States from acting in that field (Cremona, 2011, p. 247). As a consequence, in those areas of exclusive competence, the EU has taken on full responsibility for ensuring compliance with the CRPD both by itself and its Member States. This is significant as much of the more recent EU consumer protection law amounts to common rules, rather than minimum standards (Howells et al., 2018, p. 4; Unberath \& Johnston, 2007, p. 1254). A "full" or "total harmonisation" EU consumer protection measure "imposes upon the Member State a relatively strict set of uniform provisions precluding the national legislature from deviating from the policy decisions contained therein" (Unberath \& Johnston 2007, p. 1271). This approach is "usually underpinned by concerns that allowing too much legal fragmentation would be detrimental to the operation of the internal market" (Howells et al., 2018, p. 94).

A second way in which the CRPD is potentially relevant for understanding EU consumer protection law concerns its impact on how the Court of Justice of the European Union interprets secondary EU law. ${ }^{6}$ The Court has held as early as 1974 that international agreements concluded by the EU "form an integral part of the Community [now Union] legal system" (C-181/73 Haegeman v. Belgium, para 5) and that the Court has the jurisdiction to interpret the provisions of such agreements (C-282/73 Haegeman v. Belgium, para 6; C-12/96 Demirel v. Stadt Schwäbisch Gmünd). The TFEU also briefly addresses the status of international agreements to which the EU is a party in Article 216(2) TFEU, which provides "[a]greements concluded by the Union are binding upon the institutions of the Union and on its Member States." This does not explicitly indicate the hierarchy of such agreements and treaties within the EU legal order. However, the Court of Justice has addressed this lacuna in its case law. The Court has therefore established a hierarchy of norms, whereby international agreements concluded by the EU are inferior to primary law but superior to secondary law (C-366/10 Air Transport Association of America and Others, para 50, and, in the context of disability and the CRPD specifically, C-335/11 and C-337/11 HK Danmark (Ring and Skouboe Werge), paras 28-29).

Given this hierarchy, the Court is bound to interpret secondary EU law which falls within the scope of an international agreement concluded by the EU in a manner which is consistent with that agreement to the extent that this is possible (C-61/94 Commission v. Germany, para 52; C-341/95 Bettati v. Safety Hi-Tech, para 20). The Court established this in Commission v. Germany, in which it held "the primacy of international agreements concluded by the Community over provisions of secondary Community legislation means that such provisions must, so far as is possible, be interpreted in a manner that is consistent with those agreements" (para. 52). In light of this, it is no surprise that the Court and its Advocate Generals have recognised the Convention as part of EU law, and that it has influenced the interpretation of EU secondary legislation. The first judgment in which this approach was set out was HK Danmark (Ring and Skouboe Werge) which concerned the interpretation of the Employment Equality Directive (Directive 2000/78/EC) which prohibits

\footnotetext{
5 See also Article 3(2) TFEU which specifies that the Union has exclusive competence for the conclusion of an international agreement, inter alia, "in so far as its conclusion may affect common rules or alter their scope.".

6 This text draws on Lisa Waddington (2018).
} 
employment discrimination inter alia on the ground of disability. The Court noted in its preliminary observations that "[i]t follows from Decision 2010/48 that the European Union has approved the UN Convention. The provisions of that convention are thus, from the time of its entry into force, an integral part of the European Union legal order." (para. 30). ${ }^{7}$ The Court concluded, in line with established case law, that "[i]t follows that Directive 2000/78 must, as far as possible, be interpreted in a manner consistent with that convention" (para. 32 ), and proceeded to endeavour to interpret the concept of disability in the Directive in line with the CRPD.

To date, the Court has not been called upon to interpret EU consumer protection law in the context of a case involving a disabled consumer since the EU's conclusion of the CRPD; however, were it to do so, one would expect the Convention to be taken into account in light of the Court's established case law, and for the Court to endeavour to interpret that EU legislation in a CRPD-compatible manner. This would include taking into account the CRPD duties to provide a reasonable accommodation for a disabled individual and the obligations concerning accessibility.

An additional human (or fundamental) rights instrument which may impact on the interpretation of EU consumer protection law is the EU Charter of Fundamental Rights. Article 21 of the Charter prohibits discrimination on a number of grounds, including disability, and Article 38 specifies that EU policies shall ensure a high level of consumer protection. Article 26 provides for the integration of persons with disabilities. The latter article provides that:

The Union recognises and respects the right of persons with disabilities to benefit from measures designed to ensure their independence, social and occupational integration and participation in the life of the community.

As is well known, the Charter applies to all EU institutions and bodies, as well as to Member States when "they are implementing Union law" (Article 51(1)). Ferri has argued that Article 51(1) of the Charter "requires a connection with EU law. This connection is said to exist when member states are applying a provision of EU law..., or are applying a national law that transposes EU legislation, or that is otherwise intended to implement EU law or pursues its objectives." (Ferri, 2020, p. 293).

In light of this, one can argue that both the EU consumer protection directives and the national measures adopted to transpose them must be interpreted in light of the Charter, as well as in light of the CRPD. Indeed, the two instruments can bolster each other, especially taking into account the broad prohibition of disability discrimination in the Charter, and the CRPD's more detailed understanding of discrimination as including a failure to make a reasonable accommodation. The concept of reasonable accommodation is considered further in the next section.

${ }^{7}$ Decision 2010/48 is the instrument by which the EC (now EU) provided for conclusion of the CRPD. 


\section{Reasonable Accommodation and Persons with Disabilities}

A reasonable accommodation is an adjustment or change to a policy, practice, or action to meet the needs of a person with disabilities to ensure that that person has equal access to the relevant benefit as people without disabilities. An example might be providing information in Braille to meet the needs of a blind person who reads text in this format, or providing information in an easy-to-read format for a person with an intellectual disability. The provision of information in an alternative format to consumers with a disability is therefore an example of such an accommodation. This is also true, in some cases, for the provision of information with a different content.

The obligation to make a reasonable accommodation on the grounds of disability is based on the recognition that, on occasions, the interaction between an individual's impairment and the physical or social environment can result in the inability to perform a particular activity in the conventional manner. The characteristic of impairment is relevant in that it can lead to an individual being faced with a barrier that prevents him or her from benefiting from an opportunity that is open to others who do not share that characteristic. This barrier can be removed through an individualised and tailored reasonable accommodation. The individualised element of the accommodation is important, and an assessment of the needs of a particular person, and how to meet those needs, is required. The duty to provide an accommodation to a disabled individual is not absolute, and can be removed when providing the accommodation would result in a disproportionate burden for the duty bearer. ${ }^{8}$

The duty to provide a reasonable accommodation is established in the CRPD. Article 5(3) of the CRPD links the equality and non-discrimination norms with the duty to accommodate and provides that: "In order to promote equality and eliminate discrimination, states parties shall take all appropriate steps to ensure that reasonable accommodation is provided." Article 5(3) should be read together with the definition of reasonable accommodation in Article 2, which provides:

'Reasonable accommodation' means necessary and appropriate modification and adjustments not imposing a disproportionate or undue burden, where needed in a particular case, to ensure to persons with disabilities the enjoyment or exercise on an equal basis with others of all human rights and fundamental freedoms.

The CRPD explicitly defines an unjustified denial of a reasonable accommodation as a form of discrimination and extends this duty to all human rights and fundamental freedoms. This duty differs from the provisions addressing accessibility, and particularly Article 9 in the CRPD, which was discussed above. A reasonable accommodation duty is owed to a specific individual with a disability who is facing a barrier, and is usually only triggered once an individual is hampered by such a barrier, while the obligation to provide accessibility involves the development of systems designed to be usable by as many people as possible. However, such systems may still not address everyone's requirements, and a reasonable accommodation may then be required to meet the needs of a particular individual with a disability. Under the Convention, States Parties are under a duty both to provide such accommodations themselves, and to impose such obligations on private parties, when needed to protect the enjoyment and exercise of human rights and fundamental freedoms.

8 Text in this paragraph draws on Lisa Waddington (2007). 
The right of a person with a disability to a reasonable accommodation in the context of employment is found in EU law in the Employment Equality Directive. Article 5 of that Directive provides:

In order to guarantee compliance with the principle of equal treatment in relation to persons with disabilities, reasonable accommodation shall be provided. This means that employers shall take appropriate measures, where needed in a particular case, to enable a person with a disability to have access to, participate in, or advance in employment, or to undergo training, unless such measures would impose a disproportionate burden on the employer.

While the reasonable accommodation duty is only explicitly set out, using this terminology, in EU law in the Employment Equality Directive, some other provisions of EU law, including the consumer protection directives, include requirements or recommendations to make adaptions to meet the needs of disabled individuals, although the language used is sometimes obtuse and imprecise. These provisions are examined further below.

\section{EU Consumer Protection Law, Access to Pre-Contractual Information, and Consumers with Disabilities}

EU consumer protection legislation addresses, inter alia, the information which consumers must receive prior to entering into a contract. Information provision is seen as a means of enabling consumers to make an informed choice, and therefore a key aspect of consumer protection. This section of the paper examines some of the most important EU instruments concerning consumer information, and considers whether an obligation on traders to provide a de facto reasonable accommodation to consumers, in the form of accessible and appropriate information which takes account of the needs of a disabled individual, can be read into those Directives. In that context, the paper examines the Unfair Commercial Practices Directive, the Consumer Credit Directive, and the Consumer Rights Directive. This section also considers the potential relevance of, and remaining scope for, Member State action concerning accessible pre-contractual information for consumers with disabilities.

\section{The Unfair Commercial Practices Directive}

Under the Unfair Commercial Practices Directive, traders are prohibited from using unfair, misleading, or aggressive practices. This is a negative obligation. According to Article 5(2) of the Directive, commercial practices are considered to be unfair if they fail to comply with the requirement of professional diligence and materially distort the economic behaviour of the average consumer, who is assumed to be reasonably well informed, reasonably observant and circumspect (Directive 2005/29, Recital 18; C-210/96 Gut Springenheide, para. 31; C-122/10 Konsumentombudsmannen2005/29 v. Ving Sverige AB, para. 22). Writing in the broader concept of the provision of pre-contractual information to consumers under EU law, Unberath and Johnson argue "the conceptualization of the reference ['average'] consumer has clear implications for national regulatory autonomy, in the sense that it deprives each Member State of the ability to adopt national legal rules which seek to protect a wider range of consumers than merely those of reasonable circumspection" (Unberath and Johnston 2007, pp 1250-1251). This is true in the context of the Unfair 
Commercial Practices Directive, since it provides for "full harmonisation" (Recital 15) and "approximates" the laws of the Member States in this field (Article 1).

The Directive also addresses the targeting and exploitation of "particularly vulnerable" consumers (Incardona \& Poncibò, 2007). Article 5(3) of the Directive therefore awards additional protection to "a clearly identifiable group of consumers who are particularly vulnerable" to a certain commercial practice or product. Commercial practices which are likely to "materially distort the economic behaviour" of such specifically "vulnerable" consumers will be assessed from the perspective of the average member of that group (Article 5(3)). "Vulnerability" for the purpose of the Directive may arise out of the consumers' "mental or physical infirmity, age, or credulity," and therefore clearly includes certain people with disabilities, even if the language used is out of line with the CRPD (Article 5(3) and Recital 19). ${ }^{9}$

The Directive defines action which "materially distort[s] the economic behaviour of consumers" as "using a commercial practice to appreciably impair the consumer's ability to make an informed decision, thereby causing the consumer to take a transactional decision he would not have taken otherwise" (Article 2(e)). Such a practice can relate to the information which is provided, including the omission of important and relevant information (Article 7). In this respect, the Directive covers both misleading actions, including a practice which contains false or deceptive information, and the omission of material information needed by the consumer to take an informed decision. In terms of the information provided to the "vulnerable" consumer, the trader must have been "reasonably expected to foresee" the "vulnerability" of the consumer (Article 5(3)) before the duty to provide additional protection is triggered.

In light of these restricted additional requirements, several commentators have noted the limited nature of the additional protection provided to "vulnerable" consumers under the Directive. Wilhelmsson has argued that Article 5(3) "only concerns vulnerable groups that are 'clearly identifiable' [and] it is primarily useful with regard to certain particular groups of consumers as for example children, if a practice is considered sufficiently to affect such groups" (Wilhelmsson, 2007, p. 211), while Weatherill has concluded that "vulnerable consumers are sacrificed to the interests of self-reliant consumers in deregulation, market integration and wider choices" (Weatherill, 1999, p. 58). Article 5(3) on "vulnerable" consumers is not an article which has been the subject of frequent preliminary references to the Court of Justice, and the Court has not been required to interpret it in the context of people with disabilities.

In terms of the duty to adapt the content of the information which is provided to consumers with a disability, or, in the language of the Directive, "vulnerable" consumers, ${ }^{10}$ a trader is only required to act if he/she could be "reasonably expected to foresee" the "vulnerability" of the consumer. This requires quite some foresight and understanding on the part of the trader. The trader is first required to know that a certain group of consumers, such as people with an intellectual disability, are particularly "vulnerable" when provided with the usual information supplied to potential consumers, and then to realise that the specific person with whom the trader is dealing is a member of that group. Lastly, the trader is expected to know what information or omission is unfair or misleading for a particularly "vulnerable" consumer. However, if a particular consumer with a disability, or a third party, communicates all this information to a trader, one

\footnotetext{
9 For criticism of this terminology and approach see Wiesbrock (2015, p. 87).

10 The reference to "vulnerable" consumers naturally covers more than just disabled individuals.
} 
could argue that a duty to adapt the information is established. This duty is akin to the duty to provide a reasonable accommodation, in that it is individualised in nature and intended to remove barriers experienced by people with disabilities, although no reference is made to disproportionate burden in the Directive.

From the perspective of information provided to consumers with disabilities, the Unfair Commercial Practices Directives seems, at first glance, to address only the content of the information, rather than the format in which it is provided. In that sense, a commercial practice can be misleading if it omits material information (that the average consumer needs) (Article 7). However an omission to provide information in an accessible format, such as Braille or in easy to read language, does not seem to be an omission "caught" by the Directive.

Nevertheless, some limited scope for providing pre-contractual information in accessible formats may result from the case law of the Court of Justice. The Court has addressed the form in which pre-contractual information, and specifically an invitation to purchase, is provided to consumers. The Directive provides that such an invitation involves "a commercial communication which indicates characteristics of the product and the price in a way appropriate to the means of commercial communication" (Article 2(i)). In C-122/10 Konsumentombudsmannen v. Ving Sverige AB, the Court held that "a verbal or visual reference to the product" could meet the requirement relating to the indication of the product's characteristics in some cases (para. 49). Information provided in such formats could meet the needs of some people with disabilities who have difficulty understanding or reading standard written text. However, the Court has not required traders to provide information in such formats when this is needed by a consumer with a disability, and has indicated that it is for national courts to determine, on a case by case basis, whether the consumer has sufficient information "to identify and distinguish the product for the taking of a transactional decision" (para. 49).

The Court of Justice has also held that, in determining whether a commercial practice is a misleading omission under the terms of the Directive, "consideration should be given to the context in which that practice takes place, in particular the limitations of the communications medium used for the purposes of that commercial practice, the limitations of time and space imposed by that communications medium and any measures taken by the trader to make the information available to consumers by other means" (Case C-611/14 Canal Digital Danmark A/S, para. 35). Some communication mediums are clearly limited in that they are inaccessible to certain people with disabilities. If understood in this way, the judgment might indicate that inaccessible communication mediums might be "compensated" for by a trader taking other measures to make information available and accessible to a consumer with a disability.

Nevertheless, it seems difficult to conclude with any confidence that the Unfair Commercial Practices Directive establishes a duty to provide a reasonable accommodation in the form of accessible information to consumers with disabilities. However, the case law of the Court of Justice may open the door for traders to meet the requirements of the Directive by providing information in alternative and accessible formats to consumers with disabilities. Furthermore, a limited duty to provide additional information to consumers with disabilities may exist under the Directive in certain circumstances, and as long as the trader is aware that the consumer is "vulnerable."

A comparison between the obligation to provide accessible or additional information to consumers with a disability and the reasonable accommodation obligation, as well as the relevance of the fact that EU consumer protection directives largely establish "full 
harmonisation" in light of the CRPD, is discussed further in the next section covering the Consumer Rights Directive.

\section{The Consumer Credit Directive}

A second important instrument worth considering in this context is the Consumer Credit Directive, which ensures that all consumers receive certain specified information regarding credit agreements, as well as facilitating and promoting an internal market in consumer credit. For both these reasons, the Directive provides for "full harmonisation" (Directive 2008/48, Recital 9). The preamble to the Directive makes repeated reference to the importance of providing consumers with adequate information so that they can "make their decisions in full knowledge of the facts" (Recital 19). The main body of the Directive requires that certain specified information concerning consumer credit be provided in a variety of documents, agreements, and forms of communication, including in the areas of advertising (Article 4), pre-contractual information (Article 5), overdraft facilities and certain specified credit agreements (Article 6), and credit agreements (Article 10). In some cases, the Directive states that the required information should be specified "in a clear, concise, and prominent way" (Article 4(2)), or be provided on paper or another durable medium and be provided in a "clear and concise manner" (Article 5(1)). The pre-contractual information supplied should enable the consumer to take an informed decision as to whether to conclude a credit agreement (Article 5(1)). Article 5 also contains a long list of information which consumers must be provided with, including inter alia the type of credit and the borrowing rate charged.

Unlike the Unfair Commercial Practices Directive and the Consumer Rights Directive which is discussed below, the Consumer Credit Directive makes no reference to "vulnerable consumers" or, on the face of it, requires that additional steps be taken to protect such consumers. However, it is nevertheless possible to read a duty to provide a de facto accommodation, in terms of providing accessible and additional information for consumers with disabilities, into the Directive. While the Directive was adopted prior to the EU's conclusion of the CRPD, it should now be interpreted in light of the Convention. In particular, in addition to the emphasis on the provision of information to all consumers which is clear and prominent, Article 5(6), concerning pre-contractual information provided to consumers, and Recital 27 are both important in this respect.

Under Article 5(6), Member States are to ensure that creditors and credit intermediaries:

provide adequate explanations to the consumer, in order to place the consumer in a position enabling him to assess whether the proposed credit agreement is adapted to his needs and to his financial situation, where appropriate by explaining the precontractual information to be provided ..., the essential characteristics of the products proposed and the specific effects they may have on the consumer, including the consequences of default in payment by the consumer. Member States may adapt the manner by which and the extent to which such assistance is given, as well as by whom it is given, to the particular circumstances of ... the person to whom it is offered .... (Article 5(6)).

Howells, Twigg-Flesner and Wilhelmsson argue that the "the thrust of this provision is [...] for the most part about making the information transparent" (Howells et al., 2018, p. 242). While the article does not refer to consumers with disabilities, it seems clear that the 
article does allow scope for addressing the specific needs of members of this group, including through the provision of accessible and personalised information.

In addition, Recital 27 to the Preamble provides that " $[\mathrm{w}]$ here appropriate, the relevant pre-contractual information, as well as the essential characteristics of the products proposed, should be explained to the consumer in a personalised manner so that the consumer can understand the effects which they may have on his economic situation." This personalised approach is also at the heart of the reasonable accommodation duty, where the accommodation or adjustment provided should meet the needs of the individual in question, and differ from the standard approach as far as this is necessary.

However, it is worth noting that neither Article 5(6) nor Recital 27 is directed to a pre-defined group of consumers, and instead seems to recognise that all consumers may potentially struggle to understand information related to financial matters. In that sense, they partially reflect the principle of "responsible lending," which is also embodied more explicitly in Recital 26 of the Directive (Howells et al., 2018, pp. 245-246). Article 5(6), as well as Recital 27, should therefore not be understood as only relevant in the context of consumers with disabilities. In addition, unlike the reasonable accommodation duty, there is no limitation, in the form of the existence of a disproportionate burden.

In light of Article 5(6) and Recital 27, the Directive seems to expect that additional efforts are made by traders to explain the nature of credit agreements to consumers who would have difficulty understanding the standard information as provided for in the Directive, or understanding the individual implications of purchasing the product. Such consumers could include some people with intellectual disabilities or psychosocial disabilities. It could also potentially include people with visual impairments, who are not able to read the information provided in standard formats but could read and understand that same information when presented in an accessible format. The references to providing "adequate explanations" (Article 5(6)) and information which is "explained" (Recital 27) arguably cover not only the content of that information, but also the format in which the information is presented-i.e., on paper, in an accessible Word document, Braille, or through sign language.

It can be argued that Article 5(6) and Recital 27, along with the general emphasis the Directive places on providing clear information for all consumers to enable them to make an informed decision in the complex world of credit agreements, means that the Directive's information requirements should, following the EU's conclusion of the CRPD, be interpreted as including a duty to provide information in an accessible manner for consumers with disabilities. The fact that the Directive provides for "full harmonisation" is relevant in reaching this conclusion. It has been noted above that the CRPD addresses the provision of information in accessible formats and that the EU has taken on full responsibility for compliance with the CRPD by itself and its Member States in those areas where it has adopted "common rules." To a large extent, the Consumer Credit Directive provides for "full harmonisation," and can be regarded as such a "common rule," meaning that the EU has exclusive competence in this field. In light of that, and in light of the status of the CRPD as EU law, it is submitted that the Directive should be interpreted as encompassing a duty to provide information in an accessible manner, which can be understood as a de facto reasonable accommodation duty.

Nevertheless, it is worth noting that Article 5(6) does allow Member States to "adapt the manner by which and the extent to which such assistance [concerning pre-contractual information] is given as well as by whom it is given, to the particular circumstances of ... the person to whom it is offered," meaning that some residual competences remain with the Member States in this field. The relevance of this for establishing pre-contractual 
information requirements for consumers with disabilities, and the interpretation of the Directive, is discussed further below in the section on "Remaining Scope for Member State Action and Risk of National Divergences".

\section{The Consumer Rights Directive}

A third important instrument is the Consumer Rights Directive, which lays down rules for the "common aspects of distance and off-premises contracts" (Directive 2011/83, Recital 2 and Chapter III) and other contracts (Chapter II), including contracts for the supply of digital content (Articles 5 and 6) and utilities such as water, gas, and electricity (Article 3(1)). The Directive provides for "full" or "maximum harmonisation" with regard to consumer information and the right of withdrawal from such contracts, although this is subject to the comments made below in the section on "Remaining Scope for Member State Action and Risk of National Divergences".

Under the Directive, traders are to be required to provide consumers with specific information prior to the consumer being bound by a contract. The Directive lists the information to be provided to consumers, including the main characteristics of the goods or services, the identity of the trader, the total price, arrangements for payment, delivery and performance, and the duration of the contract (Articles 5 and 6). All this information is to be provided in a "clear and comprehensible manner" (Articles 5(1) and 6(1)). For off-premises contracts, the trader shall provide the information on paper or, if the consumer agrees, on another durable medium. The information shall be "legible and in plain, intelligible language" (Article 7(1)). In the case of distance contracts, the information should be provided to the consumer "in a way appropriate to the means of distance communication used in plain and intelligible language" and, if provided on a durable medium, be "legible" (Article $8(1))$. The Directive therefore pays quite some attention both to the kind of information consumers must receive, and the comprehensibility of that information.

In line with the EU's approach to consumer protection (Howells et al., 2018, p. 3, pp. 6-7 and p. 95), the "average" consumer is the standard against which compliance with the information requirements is to be assessed, although this is not stated explicitly in the instrument. In addition, the Directive refers to "particularly vulnerable" consumers. Recital 34 of the Preamble states that in providing clear and comprehensible information to the consumer prior to the completion of any contract, the trader "should take into account the specific needs of consumers who are particularly vulnerable because of their mental, physical or psychological infirmity, age or credulity in a way which the trader could reasonably be expected to foresee." This could be regarded as a call for traders to provide the necessary information in an accessible manner for a consumer with a disability-i.e., to make a de facto accommodation for a disabled consumer in terms of information provision. However, the trader will first need to be aware that an individual consumer has specific needs concerning information communication which are not met through the provision of information in the standard format and with the standard content. This is similar to the reasonable accommodation duty, which is only triggered when the duty bearer becomes aware that an individual has a disability and is experiencing barriers, and therefore requires an accommodation. A trader could realise this through interacting with the consumer, or when the consumer or a third party requests that information be provided in a non-standard, but accessible format, for a disability-related reasons. Unlike the reasonable accommodation duty, any resulting obligation is not explicitly subject to the limitation that providing the 
necessary information does not amount to a disproportionate burden, although it is subject to the limitation that it does not lead to different levels of consumer protection (Recital 34).

While provisions in the preamble to a Directive are not binding, it is submitted that a legal duty to provide a de facto reasonable accommodation in the form of accessible information can nevertheless be read into the Consumer Rights Directive. This is a result, firstly, of the general importance placed on the provision of comprehensible information in the Directive, and secondly, and in particular, as flowing from the obligations accepted by the EU when it concluded the CRPD. The preamble also makes it clear that the provision of information in adapted formats for consumers with disabilities is compatible with the Directive. These three elements arguably lead to the conclusion that the requirements set out in Recital 34 should be read into the Directive, and it should be interpreted as establishing a legal duty for traders to provide accessible information to consumers with disabilities, subject to the requirements set out below (the section on "Remaining Scope for Member State Action and Risk of National Divergences").

\section{Remaining Scope for Member State Action and Risk of National Divergences}

The argument has been made above that, because the Unfair Commercial Practices Directive, the Consumer Credit Agreement and the Consumer Rights Directive are all explicitly "full harmonisation" directives, they should be regarded as covering fields in which the EU has taken on exclusive competences, and therefore fields in which the EU bears full responsibility for ensuring compliance with the CRPD. Indeed, the Consumer Rights Directive provides: "Member States shall not maintain or introduce, in their national law, provisions diverging from those laid down in this Directive, including more or less stringent provisions to ensure a different level of consumer protection, unless otherwise provided for in this Directive." (Article 4). However, on closer reading, the Consumer Rights Directive does allow some room for additional Member State action in the context of pre-contractual information for certain kinds of contracts. Specifically Article 5(4) of the Directive provides: "Member States may adopt or maintain additional pre-contractual information requirements for contracts to which this Article applies." The Article covers contracts other than distance or off-premises contracts and sets out the information which consumers must receive, such as information on the main characteristics of the good or service and the identity of the trader. In addition, Article 6(7), which concerns information requirements for distance or off premises contracts, provides that "Member States may maintain or introduce in their national law language requirements regarding the contractual information, so as to ensure that such information is easily understood by the consumer."

Article 5(6) of the Consumer Credit Directive, which was discussed above, also allows room for additional Member State action regarding pre-contractual information. Indeed, Howells, Twigg-Flesner, and Wilhelmsson argue that it is "not uncommon for a [consumer protection] directive to have a main maximum harmonisation clause, but then to expressly provide certain provisions are subject to minimum harmonisation" (Howells et al., 2018, p. 22) and they note that this is the case with Article 5 of the Consumer Rights Directive (Howells et al., 2018, p. 103). Unberath and Johnston also acknowledge this and argue that, where EU consumer protection law "allows for alternative legal regimes applicable alongside the rules implementing the directive ... difficult questions arise as to which derogations may be tolerated" (Unberath \& Johnston, 2007, p. 1271). 
In contrast, Article 7 of the Consumer Credit Agreement, which addresses formal requirements for off-premises contracts, provides "Member States shall not impose any further formal pre-contractual information requirements for the fulfilment of the information obligations laid down in this Directive." (Article 7(5)). A similar statement is made with regard to formal requirements for distance contracts (Article 7(10)).

Therefore, whilst it is right to regard the Consumer Credit Agreement and the Consumer Rights Directive as "full harmonisation" instruments in general, they leave scope for Member States to impose some additional obligations on traders, and this could potentially cover duties concerning the provision of pre-contractual information to consumers with disabilities. In such a case, the argument that the EU has taken on full responsibility for ensuring compliance with the CRPD in this area is undermined. However, the goal of these Directives is to "contribute to a high level of consumer protection and a better functioning of the business-to-consumer internal market" (Recital 6, Consumer Rights Directive) and "increase legal certainty for both consumers and traders" (Recital 7, Consumer Rights Directive). A situation whereby Member States each impose individual and possibly differing requirements to ensure that consumers with disabilities are provided with accessible pre-contractual information, in order to comply with the obligations they have each taken on in the context of the CRPD, would potentially involve the creation of barriers within the internal market and undermine legal certainty for both traders and consumers. The CRPD is certainly not specific as to the obligations that should be adopted in this respect, so there is room for different forms of implementation. Since the EU and its 27 Member States have taken on the obligation to ensure full compliance with the CRPD, and the EU has adopted detailed rules in the field of pre-contractual information provided to consumers to establish both high levels of consumer protection and remove barriers within the internal market, the Directives considered in this article should be interpreted in line with the CRPD, including with regard to establishing requirements to provide accessible pre-contractual information to consumers with disabilities. To do otherwise would be to risk the creation of diverging national standards which may undermine the underlying goal of the legislation. This risk can be mitigated through the establishment of high standards of protection, and, while Member States would still have the legal freedom to adopt differing (even higher) standards, the need for such action would be mitigated, and perhaps disincentivised, by CRPD-compliant requirements for accessible pre-contractual information being read into the Directives by the CJEU.

A further factor which could lead to different applications and interpretations of the relevant consumer protection provisions at the national level involves judgments handed down by national courts. Courts may adopt different interpretations of "vulnerable" consumers, and establish different levels of protection for consumers with disabilities. However, it is submitted that here too the CRPD may provide a "common" or "harmonised" approach in due course through the case law of the Court of Justice. As noted above, the CRPD has taken on the status of EU law, and secondary legislation is to be interpreted in line with the Convention as far as possible. The CRPD contains guidance on how to understand the concept of persons with disabilities in Article 1, which reads: "Persons with disabilities include those who have long-term physical, mental, intellectual or sensory impairments which in interaction with various barriers may hinder their full and effective participation in society on an equal basis with others." This text has provided the basis for the definition of disability developed by the Court of Justice in the context of the Employment Equality Directive. With regard to the Directive, the Court has defined disability as "a limitation which results in particular from physical, mental or psychological impairments which in 
interaction with various barriers may hinder the full and effective participation of the person concerned in professional life on an equal basis with other workers" (C-335/11 and 337/11 HK Danmark (Ring and Skouboe Werge, para 38).

In light of the obligation to interpret EU law in line with the Convention, it can be anticipated that the Court of Justice, if called upon, would adopt a comparable definition of disability for the purposes of other provisions of secondary EU law, taking account of the goal of the legislation and intended beneficiaries. This would include defining the concept of disability for the purposes of the consumer protection instruments considered in this paper, especially in light of the explicit recognition that "vulnerability" can arise from "mental or physical infirmity ... or credulity" and "psychological infirmity" in the Unfair Commercial Practices Directive and the Consumer Rights Directive. A common EU-wide definition of disability in line with the CRPD and developed by the Court would be compatible with both the EU's and Member State's obligations under the Convention, and would also require recognition and application by national courts, as has already been the case with the definition developed for the purposes of the Employment Equality Directive. Such an approach would also contribute to legal certainty and be in line with some previous case law in which the Court has strived to give a provision of EU law an autonomous and uniform interpretation which is applicable throughout the EU (Unberath \& Johnston, 2007, p. 1275).

\section{Post-CRPD Consumer Protection Directives and the Duty to Provide Pre-Contractual Accessible Information}

The Unfair Commercial Practices Directive and the Consumer Credit Directive were both adopted prior to the EU's conclusion of the CRPD, whilst the Consumer Rights Directive was adopted less than year after the EU's conclusion. For these reasons, one can argue that the omission of references to the CRPD or the failure to establish specific requirements to provide consumers with disabilities with accessible information was perhaps understandable, and nothing should be read into this omission in determining whether such a right exists under these Directives. However, more recently, the EU has amended a number of consumer protection instruments, including the Consumer Rights Directive (Directive (EU) 2019/2161), and failed to refer to either the CRPD or the duties of traders to provide information in an accessible format to consumers with a disability in the amending instrument, although attention continues to be paid to providing consumers with information. Other recently adopted consumer protection directives, including the 2019 Digital Content Directive (Directive (EU) 2019/770) and the 2019 Directive on certain aspects concerning contracts for the sale of goods (Directive (EU) 2019/771), also both fail to refer to the CRPD or establish specific rights in the context of consumers with disabilities, even though they address pre-contractual information provided to consumers. The recently published proposal for a new Consumer Credit Directive also does not refer to the CRPD or address specific rights for consumers with disabilities.

In contrast, the 2020 New Consumer Agenda does refer to consumers with disabilities in the context of another new instrument, the aforementioned 2019 the European Accessibility Act (EAA). However, the Commission Directorate General behind this instrument is not DG Justice \& Consumers, but DG Employment, Social Affairs \& Inclusion, and while the Act is regarded as a key disability initiative of the Commission, and is listed as such on the latter DG's homepage, ${ }^{11}$ scant information is provided on the Act on the homepage

11 See: https://ec.europa.eu/social/main.jsp?catId=1137 (accessed 14 December 2021). 
of DG Justice \& Consumers. ${ }^{12}$ Therefore, even though the EAA is referred to in the New Consumer Agenda, it is an instrument which was developed outside the framework of the DG which is behind the other instruments discussed in this paper. The Agenda also indicates that the Commission will update the guidance documents on the Unfair Commercial Practices Directive and the Consumer Rights Directive, and prepare proposals for the revision of the Consumer Credit Directive, although without referring to consumers with disabilities.

Given the topic of this paper, it is worth considering whether the EAA is of significance in terms of providing consumers with disabilities with accessible pre-contractual information. Does the EAA set out explicit requirements in this respect, which means that reflections on how to interpret the Unfair Commercial Practices Directive, the Consumer Rights Directive, and the Consumer Credit Directive in terms of accessible pre-contractual information are in fact no longer relevant? The goal of the EAA is to "contribute to the proper functioning of the internal market by approximating the laws, regulations and administrative provisions of the Member States as regards accessibility requirements for certain products and services by, in particular, eliminating and preventing barriers to the free movement of [certain] products and services covered by this Directive arising from divergent accessibility requirements in the Member States." (Article 1). The Act addresses the provision of information to consumers in accessible formats in the context of information about the product or service, accessibility features, and safety information. Obligations are addressed to manufacturers, importers, and distributors. The latter group is most likely to come into direct contact with consumers with disabilities, but, in terms of information provision, this group is only required to ensure that a product is accompanied by the required documents and by instructions and safety information (Article 10(2)), which are to be supplied by the manufacturer (Article 7). The Act does not explicitly address the information consumers should be provided with in order to be able to make an informed choice as to whether to enter into a contract or not.

Moreover, the scope of the Act is limited to certain key products and services in the internal market, including computers, smartphones, tablets, TV sets, banking ATMs and services, payment terminals, e-books and e-readers, e-commerce websites and mobile applications, and ticketing machines (Article 2). Many consumer products and services fall outside of its scope, and the Act therefore does not address any aspects of the information provided to consumer with disabilities in numerous areas. In general, the Act is concerned with the accessibility of covered products and services for people with disabilities, rather than the accessibility of the process whereby individuals take a decision whether to enter into a contract or not to purchase the covered products and services.

What then do these more recent consumer protection instruments tell us about reading a duty to provide a de facto reasonable accommodation to consumers with disabilities through the provision of accessible information at a pre-contractual stage into the three Directives discussed above? It is clear that, even post-conclusion of the CRPD, EU consumer protection legislation falling under the auspices of DG Justice \& Consumers does not (yet) contain references to the Convention or explicitly endeavour to take the implications of the Convention into account. Nevertheless, the EU remains bound by the Convention, the Court of Justice is subject to an obligation to interpret secondary legislation in a CRPD-compatible manner and has demonstrated that it is cognisant of this duty, and

\footnotetext{
12 The author of this paper was unable to find any information on the European Accessibility Act on the homepage containing information on other consumer protection instruments.
} 
the EU has taken on full responsibility for ensuring CRPD-compliance when setting completely harmonised standards. Whilst the lack of attention paid to the CRPD in more recent EU consumer protection legislation can be regarded as disappointing in light of the EU's international obligations, this does not remove the duty on Member States and the Court of Justice to interpret the instruments in a CRPD-compatible manner. Such an obligation remains, and it is submitted that such a duty, in terms of requiring the provision of accessible pre-contractual information, can be read into both the Consumer Rights Directive and Consumer Credit Directive, with a more limited duty being read into the Unfair Commercial Practices Directive, as discussed above. Moreover, whilst the EAA was not developed by DG Justice \& Consumers, it is recognised as a consumer protection instrument in the New Consumer Agenda, which also acknowledges that "a lack of accessibility can put ... people with disabilities in situations of exclusion or limit their interactions", and that such consumers have "specific consumption-related needs" (pp. 16-17). Such acknowledgements are fully in line with reading a duty to provide consumers with disabilities with accessible (pre-contractual) information into existing consumer protection instruments, although this interpretation would naturally be significantly strengthened if the planned upcoming revisions of guidelines and legislative amendments explicitly provided for such a duty.

\section{Conclusion}

This paper set out to examine whether a duty to provide consumers with disabilities with pre-contractual information in an accessible format could be read into EU consumer protection law. In making this assessment, it was important to not only study discrete consumer protection instruments, but also to reflect on the implication of the EU's conclusion of the UN Convention on the Rights of Persons with Disabilities. Whilst consumer protection is, in principle, a competence shared by the EU and its Member States, the EU has adopted a number of instruments which largely establish fully harmonised requirements, thereby limiting the scope for action of Member States in the relevant areas. The EU has full responsibility for ensuring compliance with the CRPD when adopting fully harmonised standards.

The paper examined the Unfair Commercial Practices Directive, the Consumer Credit Directive, and the Consumer Rights Directive. All three instruments place a heavy emphasis on providing consumers with information so that they can give informed consent, although all three instruments fail to establish an explicit duty to make accessible pre-contractual information available for consumers with disabilities. Nevertheless, in light of the identified recitals contained in the preambles to the Directives, and the obligations on the EU flowing from the CRPD, it is submitted that a duty to provide a de facto reasonable accommodation, in terms of accessible and personalised information, can be read into the latter two Directives, and a more limited duty, concerning the provision of additional information, can be read into the Unfair Commercial Practices Directive. Scope may also exist to interpret this last Directive as allowing for information to be provided in alternative (disability accessible) formats.

This finding is significant because to date and unlike various other areas of EU law and other provisions of secondary legislation, EU consumer protection legislation falling under the auspices of DG Justice \& Consumers has not explicitly referred to the CRPD or taken steps to implement the Convention. On the other hand, the New Consumer Agenda 
produced by DG Justice \& Consumers does recognise that consumers with disabilities have specific needs, and this may be a gradual opening of the door to the provision of greater protection of consumers with disabilities, including in the context of accessible pre-contractual information. This process could be enhanced by the reading of such a duty into existing instruments.

Acknowledgements The author is grateful to the participants of the Young Universities for the Future of Europe (YUFE) Law Conference, on Informed Consent, Comparative Perspectives on Duties to inform in the EU and the Member States (29 May 2021), Dr Agustin Parise and to two anonymous reviewers for providing feedback on a previous version of this paper.

Funding Not applicable.

\section{Declarations}

Competing Interests The author declares no competing interests.

Availability of Data and Material Not applicable.

Code Availability Not applicable.

Open Access This article is licensed under a Creative Commons Attribution 4.0 International License, which permits use, sharing, adaptation, distribution and reproduction in any medium or format, as long as you give appropriate credit to the original author(s) and the source, provide a link to the Creative Commons licence, and indicate if changes were made. The images or other third party material in this article are included in the article's Creative Commons licence, unless indicated otherwise in a credit line to the material. If material is not included in the article's Creative Commons licence and your intended use is not permitted by statutory regulation or exceeds the permitted use, you will need to obtain permission directly from the copyright holder. To view a copy of this licence, visit http://creativecommons.org/licenses/by/4.0/.

\section{References}

Cremona, M. (2011). External relations and external competence of the European Union. In P. Craig \& G. de Búrca (Eds.), The Evolution of EU Law (pp. 217-268). Oxford University Press.

Beudaert, A. (2018). Towards an embodied understanding of consumers with disabilities: Insights from the field of disability studies. Consumption Markets \& Culture, 23(4), 361-375.

Deutch, S. (1994). Are consumer rights human rights? Osgoode Hall Law Journal, 32, 537-578.

Eskyté, I. (2019). Disabled people's vulnerability in the European Single Market: The case of consumer Iinformation. Journal of Consumer Policy, 42, 521-543.

Ferri, D. (2020). The unorthodox relationship between the EU Charter of Fundamental Rights, the UN Convention on the Rights of Persons with Disabilities and secondary rights in the Court of Justice case law on disability discrimination. European Constitutional Law Review, 16, 275-305.

Grammenos, S. (2020), European Comparative Data on Europe 2020 and Persons with Disabilities, Labour market, education, poverty and health, analysis and trends. European Commission. https://ec.europa. eu/social/main.jsp?catId=738\&langId=en\&pubId=8408\&furtherPubs=yes $\quad$ accessed 24 October 2021).

Griffiths, M. A. (2014). Consumer acquiescence to informed consent: The influence of vulnerability, motive, trust and suspicion. Journal of Consumer Behaviour, 13, 207-235.

Hesselink, M. (2007). SMEs in European contract law. In K. Boele-Woelki \& W. Grosheide (Eds.), The Future of European Contract Law, Essays in honour of Ewoud Hondius (pp. 359-372). Kluwer.

Howells, G., Twigg-Flesner, C., \& Wilhelmsson, T. (2018). Rethinking EU Consumer Law. Routledge.

Incardona, R., \& Poncibò, C. (2007). The average consumer, the unfair commercial practices directive, and the cognitive revolution. Journal of Consumer Policy, 30, 21-38.

Lazer, J. (2019). The potential role of US consumer protection laws in improving digital accessibility for people with disabilities. University of Pennsylvania Journal of Law \& Social Change, 22, 185-204. 
Mak, V. (2012). The myth of the 'empowered consumer'. Lessons from financial literacy studies. Tilburg University. TISCO Working Paper Series on Banking, Finance and Services, No. 03/2012.

Maker, Y., Arstein-Kerslake, A., McSherry, B., Paterson, J. M., \& Brophy, L. (2018). Ensuring equality for persons with cognitive disabilities in consumer contracting: An international human rights law protection. Melbourne Journal of International Law, 19, 178-199.

Melish, T. J. (2007). Perspectives on the UN Convention on the Rights of Persons with Disabilities: The UN Disability Convention: Historic process, strong prospects, and why the U.S. should ratify. Human Rights Brief 14(2), 43-47.

Quinn, G. (2007). The UN Convention on the human rights of persons with disabilities. Paper on file with author.

Unberath, H., \& Johnston, A. (2007). The Double-Headed Approach of the ECJ Concerning Consumer Protection. Common Market Law Review, 44, 1237-1284.

Valant, J. (2015). Consumer protection in the EU. Policy overview. European Parliamentary Research Service (PE 565.904).http://www.europarl.europa.eu/RegData/etudes/IDAN/2015/565904/EPRS_ IDA(2015)565904_EN.pdf. (accessed 14 December 2021)

Waddington, L (2007). Reasonable accommodation. In D. Schiek, L. Waddington \& M. Bell (Eds.), Ius Commune casebook on European non-discrimination law. Hart Publishing.

Waddington, L. (2011), The European Union and the United Nations Convention on the Rights of Persons with Disabilities: A story of exclusive and shared competences. Maastricht Journal of European and Comparative Law, 431-453.

Waddington, L. (2013). Vulnerable and confused: The protection of 'vulnerable' consumers under EU Law. European Law Review, 38, 757-782.

Waddington, L. (2018), The European Union in L. Waddington and A. Lawson (Eds), The UN Convention on the Rights of Persons with Disabilities in practice: A comparative analysis of the role of courts (pp. 131-152). Oxford University Press.

Waddington, L. (2020). Exploring vulnerability in EU Law: An analysis of 'vulnerability' in EU criminal law and consumer protection law. European Law Review, 45, 779-801.

Weatherill, S. (1999). Recent case law concerning the free movement of goods: Mapping the frontiers of market deregulation. Common Market Law Review, 36, 51-85.

Wiesbrock, A. (2015). Disability as a form of vulnerability under EU and CoE law: Embracing the 'social model'? In F. Ippolito \& S. I. Sánchez (Eds.), Protecting vulnerable groups, The European human rights framework (pp. 71-94). Hart Publishing.

Wilhelmsson, T. (2007). The informed consumer v the vulnerable consumer in European Unfair Commercial Practices law: A comment. In G. Howells, A. Nordhausen, D. Parry, \& C. Twigg-Flesner (Eds.), The Yearbook of Consumer Law (pp. 211-227). Ashgate.

\section{European Union}

Council Directive 2000/78/EC establishing a general framework for equal treatment in employment and occupation, OJ 2000 No. L303/16 (Employment Equality Directive).

Directive 2005/29/EC of the European Parliament and of the Council concerning unfair business-to-consumer commercial practices in the internal market and amending Council Directive 84/450/EEC, Directives 97/7/EC, 98/27/EC and 2002/65/EC of the European Parliament and of the Council and Regulation (EC) No 2006/2004 of the European Parliament and of the Council (Unfair Commercial Practices Directive).

Council Decision 2010/48/EC concerning the conclusion, by the European Community, of the United Nations Convention on the Rights of Persons with Disabilities [2010] OJ L23/35.

Council Decision (EC) on the signing, on behalf of the European Community, of the United Nations' Convention on the Rights of Persons with Disabilities, 20 March 2007, 7407/07.

Directive 2008/48/EC of the European Parliament and of the Council on credit agreements for consumers and repealing Council Directive 87/102/EEC, [2008] OJ L133/66.

Directive 2011/83/EU of the European Parliament and of the Council on consumer rights, amending Council Directive 93/13/EEC and Directive 1999/44/EC of the European Parliament and of the Council and repealing Council Directive 85/577/EEC and Directive 97/7/EC of the European Parliament and of the Council, [2011] OJ L304/64.

Directive (EU) 2016/2102 of the European Parliament and of the Council on the accessibility of the websites and mobile applications of public sector bodies [2016] OJ L 327/1 (Public Sector Web Accessibility Directive). 
Directive (EU) 2019/770 of the European Parliament and of the Council on certain aspects concerning contracts for the supply of digital content and digital services [2019] OJ L 1/136.

Directive (EU) 2019/771 of the European Parliament and of the Council on certain aspects concerning contracts for the sale of goods, amending Regulation (EU) 2017/2394 and Directive 2009/22/EC, and repealing Directive 1999/44/EC (Text with EEA relevance.) [2019] OJ L 328/7.

Directive (EU) 2019/882 of the European Parliament and of the Council on the accessibility requirements for products and services [2019] OJ L 151/70 (European Accessibility Act - EAA).

Directive (EU) 2019/2161 of the European Parliament and of the Council amending Council Directive 93/13/EEC and Directives 98/6/EC, 2005/29/EC and 2011/83/EU of the European Parliament and of the Council as regards the better enforcement and modernisation of Union consumer protection rules, [2019] OJ L 328/7.

Communication from the Commission to the European Parliament and the Council, New Consumer Agenda Strengthening consumer resilience for sustainable recovery, Brussels, 13.11.2020 COM(2020) 696 final.

Proposal for a Directive of the European Parliament and of the Council on consumer credit, Brussels 30.6.2021, 2021/0171 (COD).

\section{Cases}

\section{European Union}

Haegeman v. Belgium (C-181/73) ECLI:EU:C:1974:41.

Demirel v. Stadt Schwäbisch Gmünd (C-12/86) ECLI:EU:C:1987:400.

Re: European Development Fund, European Parliament v. Council (C-316/91) ECLI:EU:C:1994:76.

Commission v. Germany (C-61/94) ECLI:EU:C:1996:313.

Bettati v. Safety Hi-Tech (C-341/95) ECLI:EU:C:1998:353.

Gut Springenheide (C-210/96) ECLI:EU:C:1998:361.

Air Transport Association of America and Others (C-366/10) ECLI:EU:C:2011:864.

Konsumentombudsmannen v Ving Sverige AB (C-122/10) ECLI:EU:C:2011:299.

HK Danmark (Ring and Skouboe Werge) (Joined Cases C-335/11 and C-337/11) ECLI:EU:C:2013:222.

Canal Digital Danmark A/S (C-611/14) ECLI:EU:C:2016:800.

Publisher's Note Springer Nature remains neutral with regard to jurisdictional claims in published maps and institutional affiliations.

\section{Authors and Affiliations}

\section{Waddington ${ }^{1}$}

L. Waddington

lisa.waddington@maastrichtuniversity.nl

1 Department of International and European Law, Faculty of Law, Maastricht University, Maastricht, The Netherlands 